A longer version of this papers appeared in print as:

Von Kriegstein, H. (2019). Oxymoron: Taking Business Ethics Seriously. Journal of Business Ethics Education 16: 103-134.

\begin{abstract}
Business ethics denial refers to one of two claims about moral motivation in a business context: that there is no need for it, or that it is impossible. Neither of these radical claims is endorsed by serious theorists in the academic fields that study business ethics. Nevertheless, public commentators, as well as university students, often make claims that seem to imply that they subscribe to some form of business ethics denial. This paper fills a gap by making explicit both the various forms that business ethics denial can take, and the reasons why such views are ultimately implausible. The paper argues that this type of serious engagement with business ethics denial should be an important part of the job description for teachers of business ethics.
\end{abstract}

Keywords: business ethics denial, business education, business ethics, economism, homo economicus, Sumantra Ghoshal.

Acknowledgements: I would like to thank the following individuals for comments on earlier versions and/or helping me think through these issues at various stages: Daniel Attas, Michael Baumtrog, Daniele Bertolini, Joseph Heath, Chris MacDonald, Hamish Russel, Johanna Thoma, and Matthias von Kriegstein. I have also received helpful comments from audiences at, and reviewers for, the Society for Business Ethics and the Canadian Society for the Study of Practical Ethics. Finally, I would like to thank Garrett MacSweeney for his exceptional work in helping me with the last stages of literature review. 


\title{
Oxymoron: Taking Business Ethics Denial Seriously
}

\author{
Hasko von Kriegstein \\ Ryerson University - Ted Rogers School of Management, Canada
}

\section{Introduction}

If one types "business ethics is" into a google search bar, among the first suggestions for autocompleting the phrase is "an oxymoron". This is but one indication of a widespread suspicion, in the public at large, that the world of business is more or less devoid of ethics. To some degree this may simply be the result of an apparently never-ending stream of business ethics scandals. The problem goes deeper, however. After all, unethical behaviour is pervasive in other areas of life as well. When people say that "business ethics is an oxymoron", they do not just mean that a lot of unethical stuff goes on in business; they think that there is an inherent tension between business and ethics. This is what I will call business ethics denial. ...

For an example of business ethics denial in popular commentary, consider Duff McDonald, journalist and best-selling author of books about McKinsey \& Company, and Harvard Business School. In the wake of the Cambridge Analytica scandal, Facebook's Mark Zuckerberg and Sheryl Sandberg both issued statements accepting "a responsibility to protect your data - if we can't, then we don't deserve to serve you." To this, McDonald replied in Vanity Fair: "That's a hilarious statement for those familiar with the serpentine argot of America's ruling class. Consider the use of the word 'serve' - that's the kind of nonsense they spew at McKinsey, working 'in service' of their clients when they're just as mercenary and self-interested as the next MBA." (McDonald 2018) Note that, in criticizing Facebook and McKinsey, McDonald takes for granted that MBAs are mercenary and self-interested - and is confident that his readers share this assumption. ...

The paper proceeds as follows. Part II further introduces the topic, clarifies key terms (section 1), and comments on the relationship between business ethics and enlightened self-interest (section 2). Part III introduces two forms of business ethics denial: that business needs no ethics (section 3 ), and that ethics in business is not possible (section 4). Part IV discusses the implications of holding various combinations of these. ...

\section{Clarifying the Target}

\section{Defining "Business Ethics"}

Let us distinguish an oxymoron from a contradiction in terms. A contradiction in terms ascribes logically incompatible attributes to an entity. Examples of this are "married bachelor" and "square circle". An oxymoron ascribes attributes that appear to be in tension but are not logically incompatible. Thus, when George Carlin suggested that "military intelligence" is an oxymoron, he did not say that the very meaning of the term "military" includes "not intelligent"; but rather that employing the military is typically not the smartest way of approaching a problem (while also insinuating that members of the military are dumb). Thus, calling an expression a contradiction in 
terms is to make a claim about the meaning of words; calling an expression an oxymoron is to make a claim about what is the case.

We could define "ethics" and "business" such that "business ethics" becomes a contradiction in terms. This would result, for example, from defining business as "the pursuit of profit without regard for ethical considerations". However, this (or similar) definition of "business" does not capture what we ordinarily mean by the term. For example, in September 2015, Berlin-based wire manufacturer Mutanox turned down half a million dollars from the Hungarian government to deliver razor wire to secure Hungary's border against refugees. A spokesperson for Mutanox said the company declined on ethical grounds: "Our wire is designed to prevent criminal acts. Like a burglary, for example. But fleeing children and adults are not criminals." (Hegmann 2015) Supposing Mutanox really did act from ethical motives, it would not thereby cease to be a business. One may doubt whether businesses are ever truly committed to ethical principles (more on this in section 4); to say that such ethically motivated constraint is by definition incompatible with acting as a business is patently implausible. (Yet this appears to be Elaine Sternberg's view; see Sternberg 2000: section 1)

One might say that Mutanox did the right thing without considering whether there was a business case for it. Here "business" does simply signify corporate self-interest. Thus, in the sense in which "business" features in "business case", "business ethics" would be a contradiction in terms. But this is not an interesting claim about business ethics, nor is it what people mean when they say that "business ethics" is an oxymoron. Rather, what denialists allege is that businesses never do (or never should) act on ethical grounds. In other words, according to denialists, businesses always do (or always should) go where the business case leads. These claims would be vacuous if "business" and "ethics" were logically incompatible.

For our purposes let "business" denote activities aimed at furthering commercial self-interest through means typical in a market economy. And let "ethics" denote a system of constraints on self-interested behavior that operates through people's sense of what is right and wrong; rather than through external sanctions. (Cf. Beversluis 1987: 87) These definitions are as minimal as they are contentious. (For an overview of definitions of "business ethics" see Lewis 1985) But, taken together, they provide the target that business ethics denialists have in mind: the idea that a person (or company), generally engaged in pursuing their commercial self-interest, might pass up opportunities to further said self-interest, because they believe that doing so is ethically required. ${ }^{1}$ In other words, business ethics denial as I understand it here is the denial of moral motivation in a business context.

\section{Ethics Pays}

Students taking a business ethics course are likely to be exposed to at least one of the following perspectives on the relationship between self-interest and ethics. On the one hand, many teachers of business ethics stress that being ethical is (almost) always the best policy:

\footnotetext{
${ }^{1}$ This definition of business ethics is the contrapositive to what Kenneth Goodpaster calls "teleopathy". Goodpaster (1991), 94-5.
} 
We can, I believe, legitimately make the claim that acting in ways that can be considered to be "right" and "just" and "fair" is absolutely essential to the long- term competitive success of the firm. (Hosmer 1994: 192)

On the other hand, some think that "ethics has to hurt". (Stark 1992) Daniel Attas, for example, argues that stakeholder theory can be a genuine theory of business ethics only if it requires stakeholders to be treated well when doing so is not in the best interest of the company. (Attas 2004, cf Giacalone and Thompson 2006)

While the definition provided in section 1 sides with the latter perspective, I do not mean to discourage the former. A lot of important work in business ethics is done in finding and creating ways in which being ethical and making a profit go hand in hand. (E.g. Primeaux \& Stieber 1994, Porter \& Kramer 2002, Paine 2003, Nielsen 2009) But the idea that ethics pays is not the target of business ethics denial. Few would deny that maintaining amicable relationships with stakeholders is typically good for business, and that this often requires abstaining from unethical behaviour. (Cf. Carr 1968) And even those maintaining that ethics must not get in the way of profits have no objection when there is a happy confluence of the two.

It is possible that being ethical is ultimately always the best course of action from the point of view of self-interest or profit. This is particularly plausible when we explicitly focus on the long term. Still, it seems likely that "the ethical thing to do is not always in the best interest of the firm." (Hoffman 1989, cf Corvino 2006, Bhandari \& Javakhadze 2017) Take, for example, the case of International Paper. The company was operating at a loss in 2009, when they realized that they could apply for a tax credit aimed at encouraging companies to blend biofuels into fossil fuels and thus reduce their carbon footprint. But International Paper was already using 100\% biofuels (black liquor which is a by-product of papermaking), and to qualify for the tax credit they added fossil fuels - the direct opposite of the intended effect. (Mouawad and Krauss 2009) The company was able to get 100s of millions of dollars through this scheme, more than offsetting their operating losses. This was clearly both unethical and in the best economic interest of the company (both long and short-term). It is in cases like these that the question of business ethics denial arises. Will (or should) an economic agent ever side with morality, when it conflicts with self-interest?

\section{Denial of Ethics in Business}

\section{Normative Denial}

Normative denial is the view that ethical concerns are misplaced in the business context. Normative denialists believe that, regardless of how businesspeople in fact behave, there is no need for them to be motivated by ethical considerations.

\subsection{Business as a Game}

In an often-cited piece, Albert Carr compares business to poker. In both contexts, he argues, the "ethical principles preached in churches" do not apply. His advice to those feeling compunction doing things, in the business context, that would ordinarily be considered unethical is to adopt the poker player's perspective. 
The justification [for employing a low standard of honesty] rests on the fact that business, as practiced by individuals as well as by corporations, has the impersonal character of a game ... as long as a company does not transgress the rules of the game set by law, it has the legal right to shape its strategy without reference to anything but its profits. (Carr $1968)^{2}$

While Carr's article received lots of attention, little of it has been kind. The analogy between business and poker is far from perfect. (Cf Koehn 1997) And some dis-analogies seem quite important from a moral point of view: to wit, people are rarely compelled to participate in poker games as they are to earn a living in a world dominated by business. (See Beversluis 1987: 83, Hamington 2009: 478) Moreover, Carr draws normative conclusions from factual premises. Even if we grant that business is conducted in the ruthless style of a poker game, this does not justify this behaviour. (see Allhoff 2003: 283-4) At best, it may afford an excuse for individual economic agents who cannot be expected to bear the cost of behaving ethically while nobody else does. (Cf von Kriegstein 2016: 458) An excuse is not a justification, however. (Cf Baron 2007: 22-3) Thus, the factual premise that business is like a game of poker, does not warrant the conclusion that this is ethically unproblematic. What Carr expresses, then, is a rather naïve form of normative business ethics denial. And, although I have found it a common initial attitude in undergraduates, it can be fairly easily disposed of in discussion. Some students, however, argue that Carr's vision can be justified because our economic system relies on ruthlessly competitive behaviour.

\subsection{The Invisible Hand}

The argument that business not only does abide by weakened moral standards but ought to do so starts from the premise that the function of ethics is to curb self- interested behaviour, whenever such behaviour would have socially undesirable consequences. Or, in David Gauthier's words, ethics tells us to abandon self- interest and "redirect our concerns when individual gain and mutual benefit diverge." (Gauthier 1982: 41) This assumption is combined with the supposed lesson to be drawn from Adam Smith's discussion of the invisible hand of the market: in the context of a market economy the public good is best served if all participants single-mindedly pursue their own self-interest (Smith 1776/1976, book IV, ch. 2; cf Cooper et al. 2016). ${ }^{3}$ The Economist is among the voices most consistently reminding the public of this claim:

In their economic lives, people behave as though they had no regard for the public good. Yet the outcome, through the operation of the invisible hand, serves the public good better than any social planner could ever do. (The Economist 2001)

Taken together, these two claims vindicate normative denial: if the function of ethics is to suppress self-interested behaviour when it is harmful, and the market is an arrangement in which selfinterested behaviour is never harmful, then, ethics has no place in the market. (Cf Holmes 2013: 61, Goodpaster 1991: 96)

Gauthier, who formulated this set of ideas most carefully, coined the term moral anarchism for this position.

\footnotetext{
${ }^{2}$ While explicitly referring to "legal" rights in the last sentence of the passage, it is clear from the context that Carr thinks that this is a moral right as well (that companies have the legal right to do whatever is legal would hardly need saying).

${ }^{3}$ Smith, of course, never intended his insight to be used in an argument against the necessity of business ethics.
} 
The political anarchist seeks to convince us of the presence - or at least the possibility of an order in human affairs that does not require the artifice of politics. The moral anarchist would offer us the comparable picture of a human society that neither has nor wants internal constraints - a society of peaceable and productive persons who nevertheless are without conscience. The moral anarchist would seek to convince us of the possibility of the presence of an order in human affairs that does not require the deeper artifice of morality. This order must of course have a foundation, and that foundation is individual interest. (Gauthier 1982: 41)

Gauthier argues that the perfectly competitive market is such an order. (Gauthier 1982: 42) Careful to point out that the conditions of perfect market competition could not be realized in the actual world, ${ }^{4}$ he admits the limited real- world application of his discussion. (Gauthier 1982: 54; cf Beversluis 1987: 82) This point appears often overlooked by market enthusiasts, whether they be television pundits, business students, or the journalists behind The Economist's stance against corporate social responsibility in the early 2000s. (The Economist 2001, 2005) Other examples are economist Jeffrey Dorfman's assertion that "[g]reed will drive the labor market to an equilibrium where workers are fairly paid", (Dorfman 2013) and the Cato Institute's John Allison's claim that "[t]he real problem in the world is not that people pursue their long-term rational self- interest, but that many people are self-destructive." (Allison 2015: 195)

There are two answers to this type of business ethics denial. First, the perfectly competitive market already assumes the absence of certain types of immoral behaviour, such as theft, or fraud (Wells and Graafland 2012). It may be responded that the market relies on the absence of illegal, not immoral, behaviour. But relying solely on the law is not sufficient to ensure that markets function smoothly. As Walter Schultz puts it: "economically efficient outcomes of trade require, among other things, that agents possess internal incentives to comply with a set of moral rules." (Schultz 2001: 8) In other words: business ethics.

Second, as Joseph Heath points out, moral anarchism is "bad economics. It vastly overestimates the success of [actual] market institutions ... at achieving this reconciliation [between profit motive and public good]." (Heath 2014: 14) Evidence that business ethics has an important role to play in this context comes from the fact the business cycle is correlated with economy-wide attitudes towards the importance of behaving ethically (Akerlof and Shiller 2009). This is unsurprising when we consider that the failure of real-world markets to produce the salutary effects of perfectly competitive markets is not just coincidental. Such market failures are regrettable from the societal point of view, but they are precisely the kind of environment in which individual businesses can thrive. In a seminal article on corporate strategy, Michael Porter points out that

in the economists' "perfectly competitive" industry, jockeying for position is unbridled and entry to the industry very easy. This kind of industry structure, of course, offers the worst prospect for long-run profitability. The weaker the forces collectively, however, the greater the opportunity for superior performance. (Porter 1979, 137).

Subsequently, Porter has produced hugely influential guides to corporate strategy that consist mainly of strategies to avoid and suppress the kind of competition that one would find in ideal

\footnotetext{
${ }^{4}$ This became clear when Arrow and Debreu proofed the first fundamental theorem of welfare economics by utilizing a set of extremely demanding idealizing assumptions. Arrow \& Debreu (1954).
} 
markets (Porter 1980; 1985). These facts about actual corporate strategy provide a decisive rejoinder to the invisible hand argument for business ethics denial. As Arthur Applbaum puts it:

It is one thing to think that self-interested actions lead to the greatest good by way of the invisible hand. It requires an optimism that competes with Dr. Pangloss to think that actions deliberately designed to undermine the mechanism of the invisible hand lead to the greatest good by way of the invisible hand. (Applbaum 1999, 195-6).

In order to actually achieve the promises of a well-functioning market economy, then, the invisible hand of the market needs to be assisted by both the visible hand of the government, and the "visible foot" of moral motivation (Gauthier 1982).

\section{Impossibilism}

Impossibilism is the view that business ethics, however desirable it may be, is impossible. As Zsolt Boda and Laszlo Zsolnai put it: “...some deeply rooted features of today's globalized business inhibit corporations to become... truly ethical. Corporations are embedded into an institutional system that... make ethical behavior virtually impossible or contingent at best." (Boda and Zsolnai 2016: 96). While normative denial is typically combined with an ideological commitment to laissez-faire economics, impossibilism thrives among people with otherwise very different commitments. It comes in at least three different forms, based respectively on assumptions about psychology, corporate law, and economics.

\subsection{Psychological Egoism}

The least sophisticated form of impossibilism claims that business people are constitutionally incapable of acting from any motive other than self-interest. This is a version of psychological egoism, i.e. the idea that, when you dig deep enough, the ultimate motive of every action is selfinterest. Thus, Johan Hattingh and Minka Woermann report a student expressing business ethics denial by saying that "even Mother Theresa did it for herself". (Hattingh \& Woermann 2008, 14; cf Allison 2015: 2) If everyone always necessarily did what they thought best for themselves, there would be no room for genuine ethical constraints. Psychological egoism seems attractive when people sanctimoniously claim to be acting for ethical reasons, while ultimately just looking out for themselves: chasing the benefits of appearing to be just. (see the speech of Glaucon in Plato's Republic, book II) But the undeniable existence of such types does not justify the claim that everyone always acts that way. The theory appears to be grounded in the mistaken identification of motives originating in an agent and motives geared towards the agent's selfinterest. ${ }^{5}$ In other words, while every action I freely perform must spring from a motive that is mine, there is no reason to believe that every motive that is mine is a self-interested one.

Despite being widely recognized as implausible, (see, e.g., Feinberg 2004) psychological egoism occupies a prominent place in both public and academic discourse. This is because it is the working assumption of some prominent branches of economic research (an example closely related to the concerns of this article is the application of agency theory to questions of corporate governance following the highly influential Jensen and Meckling 1976). Most economists do not claim that

\footnotetext{
${ }^{5}$ This is analogous to the dual role given to the concept of preference in revealed preference theory: preference is supposed to explain both choice and welfare. But the concept cannot play both roles simultaneously (Sen 1973).
} 
psychological egoism is true of actual people. Rather, they describe homo economicus as an idealized model, helpful in formulating theory, despite its descriptive inadequacy. However, the widespread use of the model seems to encourage taking it as literally true (Wörsdörfer 2014). This is exemplified by economism, most prominently associated with Gary Becker, according to which all human behaviour is best understood as originating from self-interested motives. (Becker 2013, cf Levitt \& Dubner 2005) This, however, flies in the face of, not only common sense, but also the robust results of experimental game theory. (Folger and Salvador 2008, Heath 2017, cf Bowles \& Gintis 2011)

For psychological egoism to be a problem for business ethics in particular, it would have to be true only of business people. Or rather, since most people are business people some of the time, it would have to apply only when people conduct business. Such a claim would be hard to motivate on psychological grounds. The more promising route for the denialist is to shift the focus. People are plainly capable of acting from motives other than self-interest and their psychology does not suddenly change when they put on a business hat. What does change is the institutional context in which they operate. And perhaps this context makes people behave as if psychological egoism was true.

\subsection{Corporate Psychopathy}

A second type of impossibilism ascribes the inability to act on motives other than self-interest to business corporations: not all people are psychopaths, as psychological egoism would have it, but all corporations are. (Cf Ladd 1970, Jones 2012) Here is Joel Bakan:

Nothing in [a corporation's] legal makeup limits what it can do to others in pursuit of its selfish ends, and it is compelled to cause harm when the benefits of doing so outweigh the costs. Only pragmatic concern for its own interest and the laws of the land constrain the corporation's predatory instincts... (Bakan 2004: 60)

Interestingly, this form of skepticism is logically incompatible with psychological egoism. Maximizing profits, after all, requires corporate officers to maximize shareholders' money rather than their own compensation packages, which they would not be able to do, if psychological egoism was true. ${ }^{6}$ (Cf Michalos 1995: 47-50, Smith 1776.1976: Book V, ch 1) Note also that the idea of corporate psychopathy has no application to business ethics outside the context of corporations. A shopkeeper in sole proprietorship who (unlike the one imagined by Immanuel Kant) treats his customers fairly from a moral motive, is compatible with corporate psychopathy (Kant 1959: section 1).

Corporate psychopathy impossibilism is grounded in the belief that corporations are required by (North-American) $^{7}$ corporate law to maximize profits. (Hinkley 2002, Bakan 2004: 35) This, in turn, would mean that to incur any genuine economic costs by adhering to moral principles would

\footnotetext{
6 The alignment of executives' self-interest and corporate profits is anything but watertight. (See Hall 2003, Maremont \& Forelle 2006, Posner 2009: 98-9) This is why the shareholder primacy view places genuinely constraints on the behaviour of corporate executives. (von Kriegstein 2015).

${ }^{7}$ Bakan's claims, contentious as they are in the North-American context, would lack even superficial plausibility in many other jurisdictions.
} 
open them up to shareholder lawsuits. This is the idea at the heart of Bakan's immensely popular The Corporation:

The corporation's legally defined mandate is to pursue, relentlessly and without exception, its own self-interest, regardless of the often harmful consequences it might cause to others. (Bakan 2004: 1-2)

Bakan here refers to the fact that corporate executives have fiduciary duties towards the corporation. According to Bakan, this means that, being tasked to manage the corporation on behalf of shareholders, managers are supposed to be loyal agents always putting shareholders' interests (assumed to be maximal share prices and dividends) first. Suppose, for example, a CEO realizes they could increase (long- and short-term) profits by laying-off half their workforce. Perhaps the CEO thinks that the harm to those losing their jobs is morally more important than the increase in profitability. If Bakan is right, the CEO is legally required to go ahead with the layoffs anyway. (Bakan 2004: 45) Thus, according to Bakan, business ethics, as defined in section 1, while not impossible, is at odds with North-American corporate law. (Bakan 2004: 37)

The natural reply is to contest Bakan's interpretation of the law. The two cases that Bakan cites most prominently in support of his interpretation, Dodge v. Ford Motor Co. and Hutton v. West Cork Railway Co, rather unambiguously endorse the view that corporations are to be run "primarily for the profit of the stockholders." (Dodge v Ford Motor Co. 1919: at 684) But those cases have not established an unambiguous legal understanding of the purpose of the corporation. (Stout 2008) The shareholder primacy view Bakan presents is one popular interpretation both of what the law should and of what it does say. (See, e.g., Hansmann \& Kraakman 2000) But it is a heavily contested view in both guises (descriptive and normative). (See Allen 1992 and Lee 2005 for descriptions of the debate; for views disputing the shareholder primacy interpretation see Blair 1998; Dunfee 1999; Stout 2012).

Second, even if we accept that the law prescribes shareholder primacy, Bakan's pessimistic conclusions do not follow. That is because shareholder primacy, even where affirmed by the courts, is rarely enforced. This is for at least two reasons:

The first reason is that there is almost always a plausible profit-oriented rationalization for an act of corporate responsibility. The second reason is that courts are loath to secondguess, in hindsight, management's business judgements. (Lee 2005: 72)

Thus, if corporate officers want to sacrifice some profits for ethical concerns, they are essentially free to do so as long as they pay lip service to shareholder value. In support of his contention that corporations act ethically only if it is profitable, Bakan cites CEOs John Browne of BP and Hank McKinnell of Pfizer. Both had instituted high-profile CSR programs but, when pressed in interviews, claimed they would pursue those programs only as long as doing so was profitable. (Bakan 2004: 45-7) This is consistent with Bakan's claims; but it is also consistent with the CEOs simply hedging their bets: as long as they claim that CSR is good for the bottom line, the business judgement rule protects them from being sued by shareholders - even in a court subscribing to 
shareholder primacy. I cannot speculate on the motives of Browne and McKinnell. But Bakan's interpretation is not established by the interviews he cites. ${ }^{8}$

Finally, it is worth considering what Bakan's view implies for firms other than corporations. The shareholder-owned corporation is structurally quite similar to co-ops owned by employees or customers. In each case, most groups interacting with the firm do so on a strictly contractual basis, while one group - the owners - acts as the residual claimant. So, in the same way that a corporation is supposed to pay out any leftover money to shareholders as dividends, a consumer's co-op is supposed to use leftover money to lower prices or issue rebates. (Hansmann 1996) Thus, if Bakan was right, we should expect the management of co-ops to be every bit as ruthless as the management of corporations. A workers' co-op, for example, would always put the interests of its employee-owners first, treating other stakeholders sharply. But we hear few complaints about "coop psychopathy". This suggests that something is awry in Bakan's analysis. ${ }^{9}$

At times Bakan alludes to another line of thinking: some corporations may forego profits for ethical reasons; but sooner or later market-competition will put an end to this. This is a third type of impossibilism.

\subsection{The Race to the Bottom}

The last type of business ethics denial, and perhaps the most popular one among my students, claims that business ethics is impossible because, over time, unethical agents outcompete ethical ones which leads to the eventual disappearance of the latter. I defined business ethics as the morally motivated passing up of economic self-interest. This means that business ethics, (almost) by definition, imposes genuine economic costs. Witness Intel's CIO Diane Bryant:

We do certainly talk a lot about the additional costs that come onto IT with all these additional ethics and security requirements. It's a very large spend for any IT organization, and it continues to grow. (Pratt 2009)

Such costs represent a competitive disadvantage vis-à-vis less scrupulous companies. (Baumol \& Blackman 1991: 5; Vogel 2005: 13) And, in a competitive climate, we should expect less competitive companies to struggle to survive. Unethical corporations will be able to offer lower prices, for example, and gain market share. (Cf Kavka 1983: 62; Sethi 1994: 806) Alternatively, in a competitive market for corporate control, ethical companies might be bought out by groups that can run them more profitably by throwing out the expensive ethics (Reich 2007: 168-73; Boda and Zsolnai 2016: 96-7). While the latter mechanism is mostly restricted to widely held public corporations, the former is not. Sole proprietors are not exempt from competitive forces. Thus, race to the bottom impossibilism is not restricted to corporations; according to it, business ethics is impossible for everyone.

\footnotetext{
${ }^{8}$ Bakan treats McKinnell's statement that "[o]ur primary mission is to sustain the enterprise, and that, of course, requires profit" as corroborating evidence for his view. (Bakan 2004: 48) But the natural reading is that McKinnell views some profit as necessary for keeping a business running. This is a far cry from an exclusive focus on profit maximization.

${ }^{9}$ Bakan suggests that if shareholders wanted to monitor the behaviour of their corporation to ensure that nothing unethical is done in their name, the corporation would have no incentive to reveal unethical behaviour to its owners (Bakan, 2004: 147). He does not appear to notice that this claim conflicts with his central contentions that a corporation has a legal obligation to do the shareholders' bidding, and that corporations follow that mandate in practice.
} 
Before turning to replies, note an important difference between race to the bottom impossibilism and the two types discussed above. Both psychological egoism and corporate psychopathy imply that business ethics, as defined in section 1, is pure fiction: economic agents foregoing profit for ethical reasons never happens, and whenever someone claims otherwise, they are hiding their true motives. In response, pointing to examples of moral motivation suffices to place the burden of proof with the denialist, who needs to explain why what looks like moral motivation is in fact just (enlightened) self-interest. By contrast, the race to the bottom denialist accepts that business ethics occurs. What they deny is that ethical agents will be able to sustain themselves in the marketplace (Lynch 2009). Thus, the first two types of impossibilists would react to the story of Mutanox passing up a big sell for ethical reasons by looking for the "real", i.e. self-interested, motivation; the race to the bottom impossibilist may accept the story as reported at face value, but would predict Mutanox' eventual demise. The cynical reply to ethically motivated behaviour is: "good luck with that!", rather than: "what are you really up to?".

An example of race to the bottom impossibilism is Richard Posner's response to the suggestion that bankers should have reduced their risk-taking in the run-up to the financial crisis of 2008 .

\begin{abstract}
There would be only one effect... : the bank would lose out in competition with its more daring competitors. ... There was a race to the bottom - or the top, depending on one's perspective. The most daring, aggressive players in the financial sandbox would ramp up the riskiness of their lending or other investing, and this would increase their returns, at least in the short run. Their timid competitors would be forced to match the daring one's strategy or drop out of the competition. (Posner 2009: 322-4)
\end{abstract}

What can we say in response? First, not every industry is as fiercely competitive as financialintermediation. Thus, in many industries firms can afford to incur the costs of being ethical, without risking the viability of their enterprise (and even many banks in those years were able to survive while behaving more conservatively). Second, firms compete on a variety of dimensions, cost being only one of them. Thus, a company that incurs higher costs on account of being ethical, may find other ways of distinguishing itself and thrive in a competitive environment. ${ }^{10}$ The considerable merit of these responses can be demonstrated by reflecting on other phenomena that persist even though they should, in principle, be driven to extinction by market pressure. Consider, for example, William Baumol's discussion of discriminatory hiring practices:

If a given wage can secure for the firm the services of a woman or a Hispanic male of ability superior to that of any Caucasian male candidate for the post, then failure to hire the superior worker constitutes waste ... [S] uch behavior will render the discriminating firm vulnerable to destruction through competition of rival enterprises whose morality on terms of social discrimination is superior [...]. (Baumol \& Blackmann 1991: 18, cf Arrow 1971)

The discussion illustrates that, while ethical behavior may often be costly, sometimes it is unethical behavior that is costly. And, of course, actual economic agents are "wasteful" in all kinds of ways: ethical, unethical, and neutral. Market pressures are likely to drive out the most outrageously

\footnotetext{
${ }^{10}$ In this context, it is worth mentioning that ethics itself can be a branding opportunity. Sethi (1994), 807. This line of thought, however, straddles the line between genuine business ethics and enlightened self-interest and is thus going to be of limited use in an argument against a denialist.
} 
wasteful practices, but there is considerable wiggle-room. This makes the continued existence of discriminatory hiring practices possible. By the same token, it opens the door for business ethics.

The most promising response to the race to the bottom impossibilist, however, is to meet them halfway. True, once a critical mass of agents in an industry is behaving unethically, it will become hard to compete while incurring the cost of good ethics. But, rather than showing the impossibility of business ethics, this points to the need for an ethical culture throughout entire industries and, ultimately, the whole economy (Congleton 2014). Plausibly, this is precisely what organizations like the Rotary Club are aiming to achieve. (Tadajewski 2017). And there is no reason to think that it is impossible. In the interview, cited above, where Intel's Bryant talks about the significant cost of ethics, she continues to call it a "must-do. It's an accepted part of the IT budget." (Pratt 2009)

\section{Four Views on Business Ethics}

We have encountered two radically skeptical claims about business ethics: that it is not needed, and that it is impossible. Each of them can be held on the basis of a different set of assumptions as shown in Figure 1.

\begin{tabular}{|c|c|c|}
\hline Type of Denial & Skeptical Belief & \multicolumn{1}{|c|}{ Ground for Holding Belief } \\
\hline Normative & $\begin{array}{c}\text { There is no need for } \\
\text { ethics in business }\end{array}$ & $\begin{array}{l}\text { (i) business is a game } \\
\text { (ii) markets function without } \\
\text { ethics }\end{array}$ \\
\hline Impossibilist & $\begin{array}{c}\text { Ethics in business is } \\
\text { impossible }\end{array}$ & $\begin{array}{l}\text { (iii) psychological egoism } \\
\text { (iv) corporate psychopathy } \\
\text { (v) race to the bottom }\end{array}$ \\
\hline
\end{tabular}

Figure 1: Types of business ethics denial

One may hold neither, either, or both of the skeptical claims. I will briefly discuss each of the four possible combinations. They are summarized in the 2x2 matrix in Figure 2.

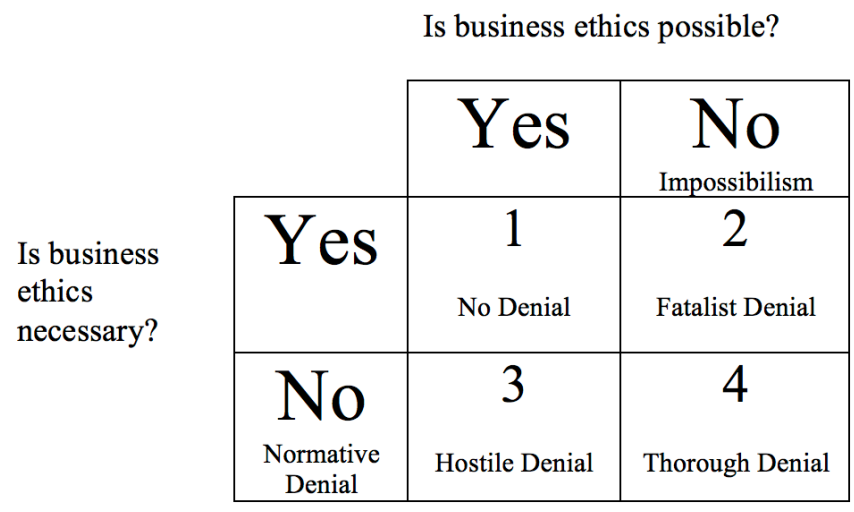

Figure 2: Conceptual space regarding business ethics denial 
In quadrants 1 and 4, normative and descriptive beliefs about business ethics are congruent. Those in quadrant 1 reject all skeptical claims explored in part III and are, thus, not business ethics denialists. This space is occupied by most mainstream business ethicists, as both the possibility and necessity of business ethics are tacitly assumed by their normative projects. And, while the focus of this article is on the considerable minority that ascribe to some form of business ethics denial, it is worth mentioning that quadrant 1 is quite possibly occupied by most members of the general public. Those occupying quadrant 4 believe that business ethics is neither necessary nor possible. This most thorough denial of business ethics is an optimistic outlook. If you believe that business ethics is impossible, you should be delighted to find we do not need it. Or, conversely, if there is no need for business ethics, you should not be troubled to find that it is impossible. Occupying either of the remaining quadrants presents a tension between normative and descriptive attitudes.

\section{Hostile Denial}

The belief that business ethics, while possible, is not necessary, is likely to result in hostility to attempts (through, for example, business ethics education) at fostering moral motivation in business. Witness the indignant tone of Milton Friedman railing against "speeches by businessmen on social responsibility" which help "to strengthen the already too prevalent view that the pursuit of profits is wicked and immoral and must be curbed and controlled by external forces." (Friedman 1970; cf Friedman 1962: 133-4. Friedman, of course, swiftly moves from the worry about moral motivation to a worry about government regulation.) Hostile denialists, then, will try to convince people that business ethics is unnecessary and thereby eradicate unnecessary (and potentially detrimental) moral motivation from the world of business.

This can create trouble for those in quadrant 1 . While generally optimistic about the possibility of business ethics, they need to acknowledge the threat posed by the race to the bottom discussed in section 4.3. This threat will be exacerbated by loud proclamations that business ethics is not necessary, since the latter view gives business(people) license to behave in purely self-interested ways. And, as noted above, once a critical mass of agents behaves in this way, it will be difficult for others to stay competitive without following suit. Thus, for those who think that business ethics is necessary, refuting the opposite view should be important. As Heath puts it,

[O]ne of the useful tasks that business ethicists can perform ... is to combat [the] extraordinary pernicious ... idea that, in a market economy, corporations have no obligation beyond respect for the law. (Heath 2014: 13)

We will return to this thought below. For now, note that, to the degree that economic agents become convinced that they are absolved from moral obligations, this creates pressure on the possibility of business ethics, and thus pushes us from quadrant 1 towards quadrant 2 (or from 3 to 4). As impossibilism is more common than normative denial, this quadrant is the one populated by most actual denialists. It is also the most interesting one in terms of the conclusions to be drawn from denialism. 


\section{Fatalism and the Reach for the State}

The most straightforward reaction to being in quadrant 2 is a kind of fatalism regarding our economic system. If we need business ethics in order for our system to work, but business ethics is impossible, our system will eventually fail. This is reminiscent of the Marxian prediction that capitalism will fail because of its internal contradictions (though the internal contradiction here is not quite what Marx described). The depth of this pessimism depends on just how important we think business ethics is. Naomi Klein, for example, thinks that, because it does not allow for business ethics, our economic system will bring about catastrophic climate change. She thinks that we will either abandon capitalism as we know it, or climate change will do the job for us. ${ }^{11}$ (Klein 2014: 95) This type of fatalism is commonly encountered when teaching business ethics to students majoring in social sciences or humanities.

Business students who believe in impossibilism often subscribe to an alternative to fatalism, namely to the idea that government regulation should to do the job that ethics cannot. Above we encountered Posner's race to bottom skepticism about business ethics. His proposed remedy is government regulation.

[This] is the reason the government has a duty, in regulating financial behavior, to do more than prevent fraud, theft, and other infringements on property and contract rights ... . Without stronger regulation than that, the rational behavior of law-abiding financiers can precipitate an economic disaster. (Posner 2009: 106-7)

Similarly, The Economist suggests that if

Western politicians ... want to stop companies from doing deals with Mr Putin's mob or be diverse, or charitable, or nice - they should pass laws not make speeches. (The Economist 2011)

The view that the government should supply the rules of the game within which competitors need not worry about ethics is widely held. (Cf Milanovic 2015) Popular author Michael Lewis describes meeting former Salomon Brothers CEO John Gutfreund shortly after the financial crisis of 2008:

[Gutfreund] thought the cause of the financial crisis was "simple. Greed on both sides greed of investors and the greed of the bankers." I thought it was more complicated. Greed on Wall Street was a given - almost an obligation. The problem was the system of incentives that channelled the greed. (Lewis 2010: 256)

Lewis agrees with Posner: ethics is impossible; we need an institutional environment that produces good outcomes despite the absence of ethics.

\footnotetext{
${ }^{11}$ It is not quite clear what Klein's view is regarding the sources of the impossibility of business ethics, but a race to the bottom scenario is plausible: businesses who do not avail themselves of the economic advantages of freely burning carbon are not going to be competitive.
} 
This is a not-too-distant cousin of the normative denial discussed in section 3.2. ${ }^{12}$ Gauthier's idea was that the ideal market is an institutional arrangement in which moral motivation is superfluous. The current suggestion is that actual markets are no such arrangement (as the financial crisis forcefully demonstrated); but that it is the government's job to regulate the market so that moral motivation becomes dispensable. (Cf Goodpaster 1999: 586; Micklethwait \& Wooldridge 2003: 191) However, this reliance on regulation is incompatible with the impossibilist assumption that successful economic agents will do whatever is in their best self-interest.

First, relying on regulation to create a system that creates socially desirable outcomes from the self-interested actions of individual economic agents presupposes that these same agents have no hand in designing the system. After all, if given the chance, the amoral agents presupposed by impossibilism would design the system in their own favour, rather than for the public good. It is a common complaint about regulation that it is simply one more rent-seeking strategy employed by powerful private actors. This is known as the regulatory capture theory of regulation. (See Stigler 1971 for a classic treatment; cf Bartel \& Thomas 1987; Thomas 1990) If this is correct, we cannot expect regulators to supply rules that steer the market towards socially desirable outcomes. Here is not the place to assess the merit of this theory. (For recent discussion see Carpenter \& Moss 2014) But it fits well with the cynical outlook at the heart of impossibilism. The assumptions driving the latter view make regulatory capture theory more plausible. This creates a tension, to say the least, in a view like Posner's who finds calls for more ethical behaviour on the part of businesspeople naïve, while, at the same time, calls for regulators to step in, as if the latter were immune to self-interested incentives.

Second, in order to rely on regulation, we need to assume that people are going to comply with the law. But this assumption is incompatible with impossibilism, because compliance with the law is itself often an instance of business ethics. To see this, consider the attitude that the economic agents imagined by the impossibilist would take towards laws and regulations: first, they would try to game the rules and exploit loopholes wherever possible. Laws are almost never fine-tuned enough to prohibit all and only the behaviours they are meant to curb. So, if we could never rely on people refraining from actions that should be illegal but technically are not, we would need to have massive numbers of incredibly detailed laws. Apart from the overwhelming difficulties of drafting and passing such laws, this would put red tape in the way of many unobjectionable projects. (Cf Yergin \& Stanislaw 2002: 368-70) Second, the imagined agents would treat laws and regulations simply as an added cost of doing business. In other words, if there is a law against, say, dumping toxins in a river, the agents imagined by the impossibilist will not say: "ah, too bad, we can't dump our toxins in the river then." They will think: "what's the probability of being caught and what's the fine? And how much do we save by dumping?" If the savings are larger than the expected fine, they will dump. This is, of course, precisely the attitude displayed in the (popular accounts of the) Ford Pinto and GM Malibu cases, which are routinely trotted out as paradigm examples of bad business ethics. ${ }^{13}$

\footnotetext{
${ }^{12}$ Goodpaster labels variations of these two views as "type $2 \mathrm{a}$ " and "type $2 \mathrm{~b}$ " thinking about business ethics respectively. Goodpaster (1991), 96-8.

${ }^{13}$ Few would go as far as Easterbrook and Fischel who describe this type of cost benefit analysis attitude towards compliance with the law not only as common, or even permissible, but as morally obligatory. Easterbrook and Fischel 1982: 1177.
} 
Thus, impossibilists must conclude that regulation will only work if it is self- interestedly rational for economic agents to follow the law. This is a troubling implication, because it would be very difficult to make following the law self- interestedly rational.

[T]he state lacks the resources and the information required to deter most crime. Given existing legal infrastructure, if people actually sat down and calculated, in a hard-headed way, how best to advance their own individual interests, then crime would be the rule rather than the exception. As a result, we (as a society) rely very heavily on internal controls (such as moral constraint) and informal social controls (such as stigmatization) to achieve conformity with legal rules. (Heath 2014: 16, cf Welling 1991: 165, Ayres \& Braithwaite 1992, Sethi 1994)

As Heath goes on to argue, because "the state has much greater difficulty detecting, prosecuting, and securing convictions" when it comes to white collar crime as compared to street crime, our reliance on voluntary compliance with the law is even more pronounced in the case of the former. (Heath 2014: 16-8)

Thus, the impossibilist faces a dilemma. S/he can either abandon the radical view that business ethics is impossible in favour of a more moderate view such as that business ethics is difficult or rare. Or s/he can stick to her guns and claim that, indeed, economic agents are constantly involved in gaming regulations and breaking the law. Examples supporting this claim will not be difficult to find. This means, however, that the idea that regulation should do the job that business ethics cannot is very radical indeed. In order for regulation to work on amoral agents, the state would have to be granted resources, and powers of investigation and punishment on a scale far from anything resembling the current political and economic order. At that point, it becomes a real question whether it might not be more efficient to simply let the state run the economy, or at least large segments of it, itself.

Thus, we are led back to the Marxist-style fatalism that this section started out with. Once we accept that business ethics is impossible, there is a strong case to be made that fatalism is the only coherent response. The impossibility of business ethics implies, all but necessarily, the impossibility of a well-functioning market economy. Those like Klein, who believe that our current economic system is doomed and the only way forward is "changing everything about how we think about the economy" (Klein 2014: 95) will embrace the implication. Everyone else needs to reconsider the plausibility of the claim that business ethics is impossible.

None of this is to deny that the state has an important role to play in regulating economic behaviour. The point is that the state can play this role only if there is a general culture of voluntary compliance with the law. Once such a culture is in place, regulation is a powerful tool. However, "follow the law, even when it is not in your best interest to do so" is an ethical norm. Thus, voluntary compliance with the law is the kind of behaviour that the denialist claims is impossible: it involves foregoing the most profitable course of action. Once it is admitted that it is possible to follow the law, even when this is economically costly, it is hard to see why incurring the costs of following other ethical rules should be impossible. ${ }^{14} \ldots$

\footnotetext{
${ }^{14}$ The one argument that suggests itself is that a law being in place reassures each agent that most agents will comply - thereby stopping, or slowing, the race to the bottom. In a well-functioning society, this is likely to be true. Indeed, this is simply to say
} 


\section{Conclusion}

There are many aspects of an environment that contribute to the ease with which people make ethical or unethical choices. In our context, however, one factor is worth singling out: the prevalence of business ethics denial! When people believe that business ethics is either unnecessary or impossible, they are less likely to adopt an ethical outlook themselves. In other words, business ethics denial furthers what psychologists call "moral disengagement", i.e. ways of cognitively processing ethically significant decisions in such a way as to behave unethically without feeling distress. (Bandura 1986: 375-389, cf Moore et al. 2012) In the case of normative denial, people will believe there is nothing wrong with acting on purely selfish motives in the business context. In the case of impossibilism, they will try to protect themselves from being suckered by everyone else. The former amounts to an offensive, the latter to a defensive violation of moral rules. (Kavka 1983: 62) Either contributes to the collective action problem described as a race to the bottom in section 4.3 .

In other words, business ethics denial can become self-fulfilling. ... [As] Heath argues ... business people are

$\ldots$ more likely to commit crimes because they have talked themselves into believing some
kind of excuse for their actions, and they have found a social environment in which this
sort of excuse is accepted or encouraged. (Heath 2014: 320)

What better excuse could there be than to believe that 'business ethics' is an oxymoron?

The goal of this article is ... to engage seriously with a number of radically skeptical claims about business ethics. To this end, I first distinguished the normative claim that there is no need for moral motivation in business, and the descriptive claim that moral motivation in business is impossible. In part III, I discussed a variety of grounds on which these claims could be held, and sketched ways in which these views can be refuted. In part IV, I used the four possible combinations of affirming or denying those claims to distinguish four types of attitude towards ethics in business. Thorough Denial accepts both skeptical claims; Hostile Denial accepts the normative skeptical claim but rejects the descriptive one; Fatalist Denial accepts the descriptive sceptical claim but rejects the normative one; and those who reject both skeptical claims are not denialists at all. [I have argued that all forms of business ethics denial are ultimately mistaken. That this is so is not obvious, however. Thus, it is worth thinking through these issues carefully, especially in light of the fact that business ethics denial, if believed by sufficient numbers, can become a self-fulfilling prophecy. We might say then, taking our inspiration from Roosevelt, that, when it comes to business ethics, we have nothing to be cynical about but cynicism itself.]

that in a well-functioning society voluntary compliance with the law is the norm. However, voluntary compliance with the law is unlikely to be the only ethical norm that is being followed in such a society. 


\section{References:}

Akerlof, G. and Shiller, R. (2009), Animal Spirits: How Human Psychology Drives the Economy and Why It Matters for Global Capitalism, Princeton: Princeton University Press.

Allen, W. (1992). Our schizophrenic conception of the business corporation. Cardozo L. Rev. 14 (1992): 261-281.

Allhoff, F. (2003). Business bluffing reconsidered. Journal of Business Ethics, 45(4), 283-289.

Allison, J. (2015). The leadership crisis and the free market cure. New York: McGraw Hill Education.

Applbaum, A. (1999). Ethics for adversaries. Princeton: Princeton University Press.

Arrow, K. and Debreu. G. (1954). Existence of an Equilibrium for a Competitive Economy. Econometrica 27: 82-109.

Arrow, K. (1971). The Theory of Discrimination. Princeton University, Department of Economics, Industrial Relations Section (Working Paper No. 30A).

Aspen ISIB (2002). Where will they lead? MBA student attitudes about business and society. Retrieved at https://dorutodpt4twd.cloudfront.net/content/uploads/files/content/docs/bsp/SAS.PD $\mathrm{F}$

Attas, D. (2004). A moral stakeholder theory of the firm. Zeitschrift für Wirtschafts- und Unternehmensethik, 5(3), 312.

Ayers, I. and Braithwaite, J. (1992). Responsive regulation. Oxford: Oxford University Press. Bakan, J. (2004). The corporation. New York: Free Press.

Bandura, A. (1986). Social foundations of thought and action. Englewood Cliffs, NJ. Baron, M. (2007). Excuses, excuses. Criminal Law and Philosophy, 1(1), 21-39.

Bartel, A. and Thomas, L. (1987). Predation through regulation: the wage and profit effects of the occupational safety and health administration and the environmental protection agency. Journal of Law and Economics 30 (2), 239-64.

Baumol, W. and Blackman, S. (1991). Perfect Markets and Easy Virtue. Cambridge: Blackwell. Becker, G. S. (2013). The economic approach to human behavior. University of Chicago press. Beversluis, E. (1987). Is there no such thing as business ethics?. Journal of Business Ethics 6, 81-88.

Bhandari, A., and Javakhadze, D. (2017). Corporate social responsibility and capital allocation efficiency. Journal of Corporate Finance, 43, 354-377.

Blair, M. (1998). For whom should corporations be run?: An economic rationale for stakeholder management. Long range planning, 31(2), 195-200.

Boatright, J. R. (1999). Does business ethics rest on a mistake?. Business Ethics Quarterly, 9(04), 583-591.

Boda, Z. and Zsolnai, L. (2016). The failure of business ethics. Society and Business Review 11(1): 93-104.

Bower, J, Leonhard, H., Paine, L. (2011). Capitalism at risk: rethinking the role of business. 
Cambridge: Harvard Business Review Press.

Bower, J. and Paine, L. (2017). The error at the heart of corporate leadership. Harvard Business Review May-June.

Bowles, S. and Gintis, H. (2011). A cooperative species: Human reciprocity and its evolution.

Princeton: Princeton University Press.

Brown, E. (2013). Vulnerability and the basis of business ethics: From fiduciary duties to professionalism. Journal of business ethics, 113(3), 489-504.

Carpenter, D. and Moss, D. (eds.) (2013). Preventing regulatory capture: Special interest influence and how to limit it. New York: Cambridge University Press.

Carr, A. (1968). Is business bluffing ethical?. Harvard Business Review (Jan.-Feb.), 143, 155.

Carruci, R. (2016). Why ethical people make unethical choices. Harvard Business Review, Dec 16. Retrieved at https://hbr.org/2016/12/why-ethical-people-make-unethical-choices

Ciulla, J. (1985). Do MBA students have ethics phobia?. Business and Society Review 53, $52-$ 54.

Congelton, A. (2014). Beyond business ethics: an agenda for the trustworthy teachers and practitioners of business. Journal of Business Ethics 119(2), 115-172.

Connors, S., Anderson_macDonald, S., Thomson, M. (2017). Overcoming the 'windowdressing' effect: mitigating the negative effects of inherent skepticism towards corporate social responsibility. Journal of Business Ethics 145(3), 599-621.

Cooper, R., Davis, M, Van Vliet, B. (2016). The mysterious ethics of high-frequency trading. Business Ethics Quarterly 26(1), 1-22.

Corvino, J. (2006). Reframing "morality pays": Toward a better answer to "why be moral?" in business. Journal of business ethics, 67(1), 1-14.

Derry, R., and Green, R. M. (1989). Ethical theory in business ethics: A critical assessment. Journal of Business Ethics, 8(7), 521-533.

Dodge v. Ford Motor Co (1919). 170 N.W. 668 (Mich 1919).

Donaldson, T. (2000). Are business managers "professionals"?. Business Ethics Quarterly, 10(01), 83-94.

Dorfman, J. (2013). Workers should be very thankful that corporations are so greedy.

Forbes.com, Dec 15. Retrieved at http://www.forbes.com/sites/jeffreydorfman/2013/12/15/corporate-greed-is-notselective-so-it-cannot-hold-down-wages/\#71672c0b4bcd

Dunfee, T. W. (1999). Corporate governance in a market with morality. Law and Contemporary Problems, 62(3), 129-157.

Duska, R. F. (1991). What's the point of a business ethics course?. Business Ethics Quarterly, 1(04), 335-354.

Easterbrook, F. and Fischel, D. (1982). Antitrust suits by targets of tender offers. Michigan Law Review, 80(6), 1155-1178.

Englander, E., Kaufman, A. (2004). The end of managerial ideology: From corporate social responsibility to corporate social indifference. Enterprise \& Society, 5(3), 404-450. 
Feinberg, J. (2004). Psychological egoism. In: J. Feinberg and R. Shafer-Landau (eds.), Reason and responsibility, 12th edn. Belmont: Wadsworth, 476-88.

Flanagan, W. (2003). Dirty rotten CEOs: how business leaders are fleecing America. New York: Citadel Press.

Folger, R. and Slavador, R. (2008). Is management theory too "self-ish"?. Journal of Management 34.

Frank, B., Schulze, G. (2000). Does economics make citizens corrupt?. Journal of economic behavior \& organization, 43(1), 101-113.

Frank, R., Gilovich, T., Regan, D. (1993). Does studying economics inhibit cooperation?. Journal of economic perspectives 7(2), 159-171.

Freeman, R. (1994). The politics of stakeholder theory: Some future directions. Business ethics quarterly, 409-421.

Friedman, M. (1962). Capitalism and freedom. Chicago: University of Chicago Press.

Friedman, M. 1970. The social responsibility of business is to increase its profits. New York Times Magazine, Sept. 13.

Gandal, N., Roccas, S., Sagiv, L., Wrzesniewski, A. (2005). Personal value priorities of economists. Human Relations, 58(10), 1227-1252.

Gauthier, D. (1982). No need for morality: The case of the competitive market. Philosophic exchange 3(3), 41-54.

Gentile, M. (2010). Giving voice to values. New Haven: Yale University Press.

Ghoshal, S., Bartlett, C. A., and Moran, P. (1999). A new manifesto for management, 9-20. Spring: Sloan Management Review.

Ghoshal, S. (2003). Business Schools Share the Blame for Enron. Business Ethics: The Magazine of Corporate Responsibility, 17(3), 4-4.

Ghoshal, S. (2005). Bad management theories are destroying good management practices. Academy of Management learning \& education, 4(1), 75-91.

Giacalone, R. and Thompson, K. (2006). Business ethics and social responsibility education: shifting the worldview. Academy of Management Learning \& Education 5(3), 266-77.

Giacalone, R. and Wargo, D. (2009). The roots of the global financial crisis are in our business schools. Journal of Business Ethics Education 6.

Giddens, A. (1984). The constitution of society: Outline of the structuration theory. Cambridge: Polity.

Gioia, D. A. (2002). Business education's role in the crisis of corporate confidence. The Academy of Management Executive, 16(3), 142-144.

Goodpaster, K. (1991). Ethical imperatives and corporate leadership. In R.E. Freeman (ed.), Business ethics: The state of the art (pp. 89-110). New York: Oxford University Press.

Green, R. (1991). When is "Everyone's Doing It A Moral Justification?. Business Ethics Quarterly, 1(01), 75-93.

Hall, B. (2003). Six challenges in designing equity based pay; Journal of Applied Corporate Finance 15 (3), 21-33.

Hamington, M. (2009). Business is not a game: the metaphoric fallacy. Journal of Business Ethics 86. 
Hansmann, H. (1996). The ownership of enterprise. Cambridge: Harvard University Press. Hansmann, H. and Kraakman, R. (2001). The End of History for Corporate Law. Georgetown Law Journal 89(2), 439-468.

Harris, J. and Freeman, R. (2008). The impossibility of the separation thesis: A response to Joakim Sandberg. Business Ethics Quarterly, 18(4), 541-548.

Hattingh, J. and Woermann, M. (2008). They are all lies. Even mother Theresa did it for herself. African Journal of Business Ethics, 3(1), 14-18.

Heath, J. (2008). Business ethics and moral motivation: A criminological perspective. Journal of Business Ethics, 83(4), 595-614.

Heath, J. (2014). Morality, competition, and the firm. Oxford: Oxford University Press. Heath, J. (2017). The contribution of economics to business ethics. In: Heath, E., Kaldis, B. and Marcoux, A. (eds.), The Routledge companion to business ethics. London: Routledge. Hegmann, G. (2015). Deutsche Firma lässt Ungarn bei Nato-Draht abblitzen. Welt.de, Sep 15. Retrieved from https://www.welt.de/wirtschaft/article146439350/Deutsche-Firma$\underline{\text { laesst- }}$

Ungarn-bei-Nato-Draht-abblitzen.html

Hinkley, R. C. (2002). How corporate law inhibits social responsibility. The Humanist, 62(2), 26.

Hoffman, M. (1989). The cost of a corporate conscience. Business and Society Review 69, 4647.

Holmes, R. (2013). The Ethics of Nonviolence: Essays by Robert L. Holmes (ed. Cicovacki, P.). New York: Bloomsbury.

Hosmer, L. T. (1994). Why be moral? A different rationale for managers. Business Ethics Quarterly, 4(02), 191-204.

Houck, J. and Williams, O. (1996). Is the good corporation dead?: social responsibility in a global economy. Rowman \& Littlefield.

Hühn, M. (2014). You reap what you sow: how MBA programs undermine ethics. Journal of Business Ethics 121(4), 527-541.

Hutton v West Cork Rly Co (1883). 23 Chancery Division 654 (C.A.).

Irving, K. (1987). Ethics, anyone? Or morals?. The Wall Street Journal, Sep 15.

Jensen, M. and Meckling, W. (1976). Theory of the firm: Managerial behavior, agency costs and ownership structure. Journal of financial economics, 3(4), 305-360.

Jones, S. (2012). If coroporations are people, they are psychopaths. Politicususa.com, Apr 19. Retrieved at http://www.politicususa.com/2012/04/19/corporations-people-

psychopaths-

2-2.html

Kant, I. (1959). Foundations of the metaphysics of morals. Translated by Beck, L. Indianapolis: Bobbs-Merrill.

Kavka, G. S. (1983). When two 'wrongs' make a right: An essay on business ethics. Journal of 
Business Ethics, 2(1), 61-66.

Khurana, R. (2007). From higher aims to hired hands: the social transformation of American business schools and the unfulfilled promise of management as a profession.

Princeton: Princeton University Press.

Klein, N. (2014). This changes everything: Capitalism vs. the climate. New York: Simon \& Schuster.

Koehn, D. (1997). Business and game-playing: the false analogy. Journal of Business Ethics, 16(12-13), 1447-1452.

Ladd, J. (1970). Morality and the ideal of rationality in formal organizations. The Monist 54(4), 488-516.

Lee, I. (2005). Is There a Cure for Corporate "Psychopathy"?. American Business Law Journal, 42(1-6), 65-90.

Levin, M. (1989). Ethics courses: useless. New York Times, Nov 25.

Levitt, S. and Dubner, S. (2005). Freakonomics. New York: William Morrow.

Lewis, M. (2010). The big short: Inside the doomsday machine. New York: Norton.

Lewis, P. (1985). Defining 'business ethics': like nailing jello to a wall. Journal of Business Ethics 4, 377-383.

Lynch, T. (2009). Legitimating market egoism. Journal of Business Ethics 84.

MacFarlane, B. (2001). Developing reflective students: Evaluating the benefits of learning logs within a business ethics programme. Teaching Business Ethics, 5(4), 375-387.

Maremont, M. and Forelle, C. (2006). Bosses' pay: how stock options became part of the problem. The Wall Street Journal, Dec 27.

Martinov-Bennie, N. and Mladenovic, R. (2015). Investigation of the impact of an ethical framework and an integrated ethcis education on accounting students' ethical sensitivity and judgement. Journal of Business Ethics 127(1), 189-203.

Marwell, G. and Ames, R. (1981). Economists free ride, does anyone else?: Experiments on the provision of public goods, IV. Journal of public economics, 15(3), 295-310.

McDonald, D. (2017). The golden passport. New York: Harper Collins.

McDonald, D. (2018). "When you get that wealthy, you start to buy your own bullshit": the miseducation of Sheryl Sandberg. Vanity Fair, Nov 27. Retrieved at https://www.vanityfair.com/news/2018/11/sheryl-sandberg-harvard-business-schoolleadership

Michalos, A. (1995). A Pragmatic Approach to Business Ethics. Thousand Oaks: Sage Publications.

Micklethwait, J. and Wooldridge, A. (2003). The Company: a short history of a revolutionary idea. New York: Random House.

Milanovic, B. (2015). Henry and Kant: outsourcing morality. Glineq.blogspot.ca, May 22. Retrieved from http://glineq.blogspot.ca/2015/05/henry-and-kant-outsourcing- 
morality.html

Moore, C., Detert, J. R., Klebe Treviño, L., Baker, V. L., \& Mayer, D. M. (2012). Why employees do bad things: Moral disengagement and unethical organizational behavior. Personnel Psychology, 65(1), 1-48.

Mouawad, J. and Krauss, C. (2009): Lawmakers may limit paper mills' windfall. New York Times, Apr 17. Retrieved from https://www.nytimes.com/2009/04/18/business/energy-

environment/18sludge.html

Nicholls, J., Hair, J., Ragland, C., and Schimmel, K. (2013). Ethics, CSR, and sustainability education in AACSB undergraduate and graduate marketing curricula: a benchmark study. Journal of Marketing Education.

Nielsen, R. (2009). Varieties of wini-win solutions to problems with ethical dimensions. Journal of Business Ethics 88(2), 333-49.

Paine, L. (2003). Value shift: why companies must merge social and financial imperatives to achieve superior performance. New York: McGraw-Hill.

Parker, M. (2018). Why we should bulldoze the business school. The Guardian, Apr 27. Retrieved from https://www.theguardian.com/news/2018/apr/27/bulldoze-the-business-school

Plato (1974). Republic. Translated by Grube, G. Indianapolis: Hackett.

Podolny, J. (2009). The buck stops (and starts) at business school. Harvard Business Review.

Porter, M. (1979). How competitive forces shape strategy. Harvard Business Review.

Porter, M. (1980). Competitive Strategy. New York: Free Press.

Porter, M. (1985). Competitive Advantage. New York: Free Press.

Porter, M. and Kramer, M. (2002). The competitive advantage of corporate philanthropy. Harvard business review, 80(12), 56-68.

Posner, R. (2009). A failure of capitalism: The crisis of '08 and the descent into depression. Cambridge: Harvard University Press.

Prasad, A. and Holzinger, I. (2013). Seeing through smoke and mirrors: A critical analysis of marketing CSR. Journal of Business Research, 66(10), 1915-1921.

Pratt, M. (2009). Ethics: Harder in a recession?. Computerworld.com, Aug 24. Retrieved at http://www.computerworld.com/article/2550326/it-industry/ethics--harder-in-a-recession.html

Primeaux, P. and Stieber, J. (1994). Profit maximization: The ethical mandate of business. Journal of Business Ethics, 13(4), 287-294.

Reich, R. (2007). Supercapitalism. New York: Alfred A. Knopf.

Reynolds, S. and Dang, C. (2017). Are the "customers" of business ethics courses satisfied? An examination of one source of business ethics education legitimacy. Business \& Society, 56(7), 947-974.

Sandberg, J. (2008). Understanding the separation thesis. Business Ethics Quarterly, 18(2), 213232.

Schultz, W. (2001). The moral conditions of economic efficiency. Cambridge: Cambridge University Press.

Schwartz, M. (2007). The "business ethics" of management theory. Journal of Management 
History, 13(1), 43-54.

Sen, A. (1973). Behaviour and the concept of preference. Economica New Series 40(159), $241-$ 259.

Sen, A. (1993). Does business ethics make economic sense?. Business Ethics Quarterly, 3(01), 45-54.

Sethi, S. (1994). Imperfect markets: Business ethics as an easy virtue. Journal of Business Ethics, 13(10), 803-815.

Shin, S. and Aleccia, V. (2014). Students' academic misconduct and attitude toward business ethics. Journal of Business Ethics Education, 11, 105-127.

Smith, A. (1776/1976). An inquiry into the nature and causes of the wealth of nations. (ed. Campbell, R., Skinner, S. and Todd, W.). Oxford: Oxford University Press.

Stark, A. (1992). What's the matter with business ethics?. Harvard business review, 71(3), 3840.

Sternberg, E. (2000). Just business: Business ethics in action $2^{\text {nd }}$ ed. Oxford: Oxford University Press.

Stearns, J. and Borna, S. (1998). A comparison of the ethics of convicted felons and graduate business students: Implications for business practice and business ethics education. Teaching Business Ethics, 2(2), 175-195.

Stigler, G. J. (1971). The theory of economic regulation. The Bell journal of economics and management science 2(1), 3-21.

Stout, L. (2008). Why we should stop teaching Dodge v. Ford. Va. L. \& Bus. Rev., 3, 163.

Stout, L. A. (2012). The shareholder value myth: How putting shareholders first harms investors, corporations, and the public. San Francisco: Berrett-Koehler.

Swanson, D. (2005). Business ethics education at bay: Addressing a crisis of legitimacy. Issues in Accounting Education, 20(3), 247-253.

Tadajewski, M. (2017). The Rotary Club and the promotion of the social responsibilities of business in the early 20th century. Business \& Society, 56(7), 975-1003.

The Economist (2001). Curse of the ethical executive. The Economist, Nov 15.

The Economist (2005). The good company. The Economist, Jan 20.

The Economist (2011). How bad is BP?. The Economist, Jan 22.

Thomas, L. (1990). Regulation and firm size: FDA impacts on innovation. The RAND Journal of Economics, 497-517.

Vogel, D. (2005). The market for Virtue. Washington: Brookings.

Von Kriegstein, H. (2015). Shareholder primacy and deontology. Business and Society Review 120 (3), 465-490.

Von Kriegstein, H. (2016). Professionalism, agency, and market failures. Business Ethics Quarterly 26(4), 445-464.

Welling, B. (1991). Corporate law in Canada: The governing principles $2^{\text {nd }}$ ed. Butterworths Canada. 
Wells, T. and Graafland, J. (2012). Adam Smith's Bourgois Virtues in Competition. Business Ethics Quarterly 22(2), 319-50.

Willen, L. (2004). Kellogg denies guilt as B-schools evade alumni lapses. Bloomberg News Wire, Mar 8.

Williams, S. and Dewett, T. (2005). Yes, you can teach business ethics: A review and research agenda. Journal of Leadership \& Organizational Studies, 12(2), 109-120.

Wörsdörfer, M. (2014). Inside the "Homo Oeconomicus Brain": Towards a Reform of the Economics Curriculum?. Journal of Business Ethics Education, 11, 5-40.

Yergin, D. and Stanislaw, J. (2002). The commanding heights: The battle for the world economy. New York: Simon \& Schuster. 